\title{
Evaluation of optimal irrigation scheduling and groundwater recharge at representative sites in the North China Plain with SWAP model and field experiments
}

\author{
Ying Ma ${ }^{\mathrm{a}, \mathrm{b}, *}$, Shaoyuan Feng ${ }^{\mathrm{c}}$, Xianfang Song ${ }^{\mathrm{a}, *}$ \\ ${ }^{a}$ Key Laboratory of Water Cycle and Related Land Surface Processes, Institute of Geographic Sciences and Natural Resources Research, Chinese Academy of Sciences, \\ 100101 Beijing, China \\ ${ }^{\mathrm{b}}$ State Key Laboratory of Soil and Sustainable Agriculture, Institute of Soil Science, Chinese Academy of Sciences, 210008 Nanjing, China \\ ${ }^{\mathrm{c}}$ Yangzhou University, 225009 Yangzhou, China
}

\section{A R T I C L E I N F O}

\section{Article history:}

Received 1 February 2015

Received in revised form 21 May 2015

Accepted 17 June 2015

Available online 1 July 2015

\section{Keywords:}

North China Plain

Irrigation scheduling

Groundwater recharge

Winter wheat-summer maize

SWAP model

\begin{abstract}
A B S T R A C T
The application of water saving irrigation is essential to alleviate the rapid depletion of groundwater resources in water crisis areas such as the North China Plain (NCP). The integrated effects of climate, soil and groundwater conditions on water balance and crop response need to be further studied. It is imperative to investigate spatial differences of irrigation scheduling and groundwater recharge within the NCP for regional water management. In this study, three representative sites including Luancheng (LC), Tongzhou (TZ) and Yucheng (YC) with different precipitation, soil and water table conditions were selected. The SWAP model was established at each site to compare optimal irrigation scheduling and groundwater recharge of the winter wheat-summer maize double cropping system under different hydrological years. Largest optimal irrigation amount and additional irrigation at the winter-dormancy stage of wheat were required for the TZ site in each hydrological year. The optimal irrigation scheduling was almost same at the three sites for summer maize, except that no irrigation was needed at filling stage in dry year at the YC site. The average annual groundwater recharge under optimal irrigation was in the order of YC (108.4 mm), TZ (63.8 mm) and LC $(0.4 \mathrm{~mm})$. Furthermore, the groundwater recharge occurred throughout the double cropping seasons in YC, but it occurred only in summer maize season at the LC and $\mathrm{TZ}$ sites. The net irrigation amount of the optimal irrigation scheduling was reduced by $51.2 \%, 24.9 \%$ and $77.2 \%$ compared to reference practice at the LC, TZ and YC sites, respectively. The amount of groundwater recharge depended on the local precipitation and irrigation, while water table depth and soil texture mainly influenced the delay time of groundwater recharge relative to the water input events.
\end{abstract}

(c) 2015 Elsevier B.V. All rights reserved.

\section{Introduction}

The North China Plain (NCP) is one of the most important food production regions in China, providing about $69 \%$ of wheat and $35 \%$ of maize grain yield of the whole country (Mo et al., 2009). This high crop yield is based on the consumption of about $79 \%$ of groundwater resources in the area. However, overexploitation of groundwater for irrigation has resulted in great groundwater level declines and many other environmental problems in the NCP (e.g., land subsidence, ecosystem degradation, and groundwater quality deterioration) (Kendy et al., 2003; Sun et al., 2010). Therefore,

\footnotetext{
* Corresponding authors at: Key Laboratory of Water Cycle and Related Land Surface Processes, Institute of Geographic Sciences and Natural Resources Research, Chinese Academy of Sciences, 100101 Beijing, China. Tel.: +86 1064889367.

E-mail addresses: maying@igsnrr.ac.cn (Y. Ma), xfsong@igsnrr.ac.cn (X. Song).
}

irrigated agriculture is facing critical challenge to produce sufficient food for a continuously increasing population but with limited water supply. Efficient irrigation water management has to be carried out to aim at saving water and maximizing its productivity (Fereres and Soriano, 2007).

Supplemental irrigation and limited or deficit irrigation are effective ways to reduce irrigation water use and improve crop water use efficiency (WUE) (Kang et al., 2002; Fereres and Soriano, 2007). In the past two decades, many field experiments were conducted in the NCP to investigate soil water balance and crop yield response under deficit irrigation. These studies focused on the relationship between evapotranspiration and grain yield, irrigation scheduling and WUE, and crop responses to water stress at different growth stages (Liu et al., 2002; Li et al., 2005; Zhang et al., 2006; Shang et al., 2009). Moreover, several simulation models (e.g., ISAREG, RZWQM and APSIM models) have been applied to 
generate the optimal irrigation scheduling strategies for winter wheat and summer maize in specific location of the NCP (Liu et al., 2006; Wang and Huang, 2008; Chen et al., 2010).

Water-saving agricultural practices, along with the declining water tables and increasing thickness of the vadose zone, have strongly affected the field water cycle, especially the groundwater recharge (Wang et al., 2008). Roman et al. (1999) presented that an improved irrigation schedule could reduce recharge compared to traditional irrigation applied by farmers. Besides irrigation, precipitation, soil type and water table also influenced groundwater recharge. In general, groundwater recharge increased with the amount and intensity of rainfall which influenced how much water entered into the soil and rocks (Edmunds, 2001; Stonestrom et al., 2007). A logarithm empirical equation was proposed to describe the relationship between the groundwater level increment and the effective accumulated rainfall amount (Jan et al., 2007). The sandy soils tended to have greater rates of recharge compared to clayey soils as the latter increased tortuosity and limited water movement (Kim and Jackson, 2012). The water table depth determined the time-lags between infiltration (rainfall plus irrigation) and groundwater recharge (Lu et al., 2011).

In the NCP, Kendy et al. (2004) showed that areal recharge in Luancheng was not a constant fraction of the plus of precipitation and irrigation, but rather the fraction increased with the increase of water inputs. Chen et al. (2010) estimated the response of recharge to historical climate (1961-2000) and irrigation, and they explored the optimal water management strategies in Luancheng using the APSIM model. Wang et al. (2008) indicated that the recharge rate in Cangzhou with silt soil $\left(0.27 \mathrm{~mm} \mathrm{~d}^{-1}\right)$ was larger than that in Dezhou $\left(0.15 \mathrm{~mm} \mathrm{~d}^{-1}\right)$ with silt clay soil. However, the integrated effects of irrigation scheduling, precipitation, soil and water table conditions on groundwater recharge were not paid enough attention in previous studies.

It is believed that the above studies have provided insights into optimal irrigation management and groundwater recharge evaluation. However, these studies were mainly limited to one specific location in the NCP, and the obtained results restricted to local conditions. The responses of water balance and groundwater recharge to irrigations are quite variable in different areas due to the spatial variability of precipitation, soil and water table conditions in the NCP. Spatial differences of irrigation scheduling and groundwater recharge and their affecting factors at multiple sites within the NCP need to be further studied. Therefore, it is imperative to choose representative sites in the NCP to reasonably establish areal irrigation scheduling and assess groundwater recharge. Due to the lack of sufficient field experimental data in multiple sites, combining the numerical model with the available field experimental data is an appropriate approach for this work.

The soil-water-atmosphere-plant model (SWAP) is an applicable and feasible tool for field water balance evaluation and irrigation management under various conditions (van Dam et al., 1997). It is a physically based agro-hydrological model with extensive features to account for soil heterogeneity and boundary conditions. The SWAP model has been tested and validated for a wide range of climate and agricultural systems in semi-arid areas (Sarwar et al., 2000; Droogers et al., 2001) including the NCP (Ma et al., 2011; Huo et al., 2012).

There are three objectives of this study. First is to establish the SWAP model at three representative sites with distinct precipitation, soil and water table conditions in the NCP. Second is to use the SWAP model to simulate the optimal irrigation scheduling and groundwater recharge under different hydrological years for winter wheat-summer maize double cropping system at the representative sites. Third is to evaluate the impacts of precipitation, soil and water table conditions on the evapotranspiration and groundwater recharge. Previous studies have a focus on crop and irrigation whereas this study has a focus on groundwater. This study is expected to present beneficial suggestions to improve agricultural water use efficiency and alleviate the groundwater resources crisis in the NCP.

\section{Study area}

The North China Plain (NCP) with an area of $140,000 \mathrm{~km}^{2}$ is located in north China $\left(34^{\circ} 46^{\prime}-40^{\circ} 25^{\prime} \mathrm{N}, 112^{\circ} 30^{\prime}-119^{\circ} 30^{\prime} \mathrm{E}\right)$. It is one of the most densely populated regions in the world with an average population of about 800 per $\mathrm{km}^{2}$. The water resource per capita is approximately $500 \mathrm{~m}^{2} \mathrm{yr}^{-1}$, only accounting for one quarter of the national average and one-fifteenth of the world average. Water shortage and groundwater over-abstraction are the critical threats to sustainable food production in this region.

The climate in the NCP is continental semi-arid, with average annual temperature of $12-13^{\circ} \mathrm{C}$. Mean annual precipitation is about $560 \mathrm{~mm}$ (1951-2008). The seasonal distribution of precipitation is uneven, with approximately $70-80 \%$ of precipitation occurring during the summer maize season from June to September (Cao et al., 2013). Regionally, average annual precipitation decreases from the southeast to the northwest, with relatively small value in the Shijiazhuang-Hengshui-Xingtai area. Mean annual pan evaporation ranges from 1100 to $2000 \mathrm{~mm}$ (Chen et al., 2005). Fu et al. (2009) have predicted that the increases of annual precipitation in 2025, 2050, and 2080 will be less than $20 \%$ in the NCP comparing with the value in the 20th century. At the end of 21st century, the evapotranspiration will increase less than $6 \%$ for winter wheat and $28.5 \%$ for summer maize under the baseline from 2000 to 2008 (Mo et al., 2009).

The NCP is divided into three main geomorphologic zones from the Taihang Mountains in the west to the Bohai Sea in the east: the piedmont plain, the alluvial and lacustrine plains (central plains), and the coastal plain (Fig. 1) (Cao et al., 2013). The water table depth in the piedmont plain is relatively deep between 8 and $45 \mathrm{~m}$, even up to $60 \mathrm{~m}$ at some locations, and the unsaturated zone consists mainly of silt and fine sand. The water table depth is in the range of $5-15 \mathrm{~m}$ in the alluvial and lacustrine plains, and soil is mainly silty clay and silt. In the coastal zone, the water table is relatively shallow with the value between 0 and $7 \mathrm{~m}$, and the major soil is silt and silty clay.

Three representative sites in the NCP were selected for the irrigation management and groundwater recharge evaluation, including Luancheng (LC), Tongzhou (TZ) and Yucheng (YC) sites (Fig. 1). The LC site is in the piedmont plain, which is located at Luancheng Agro-Eco Experimental Station ( $37^{\circ} 53^{\prime} \mathrm{N}, 114^{\circ} 41^{\prime} \mathrm{E}, 50 \mathrm{~m}$ altitude). The TZ site is located at Central Station for Irrigation Experiment of Beijing $\left(39^{\circ} 59^{\prime} \mathrm{N}, 116^{\circ} 17^{\prime} \mathrm{E}, 14 \mathrm{~m}\right.$ altitude) within the northern alluvial and lacustrine plains. The YC site is in the southern alluvial and lacustrine plains, which is located at the Yucheng Comprehensive Experimental Station $\left(36^{\circ} 57^{\prime} \mathrm{N}, 116^{\circ} 38^{\prime} \mathrm{E}\right.$, and $22 \mathrm{~m}$ altitude) within the Panzhuang Irrigation District at the lower reach of the Yellow River.

The average precipitation $(P, \mathrm{~mm})$, reference evapotranspiration $\left(\mathrm{ET}_{0}, \mathrm{~mm}\right)$ and mean temperature $\left(T_{\text {mean }},{ }^{\circ} \mathrm{C}\right)$ during the winter wheat-summer maize crop rotation was, respectively, $524 \mathrm{~mm}$, $1028 \mathrm{~mm}$ and $13.5^{\circ} \mathrm{C}$ for LC, $544 \mathrm{~mm}, 1081 \mathrm{~mm}$ and $12.4{ }^{\circ} \mathrm{C}$ for $\mathrm{TZ}$, and $556 \mathrm{~mm}, 1236 \mathrm{~mm}$ and $14.7^{\circ} \mathrm{C}$ for YC from 1961 to 2009. Obvious decreasing trends of annual $\mathrm{P}$ were observed at all the three sites, particularly for $\mathrm{YC}$ with the reduction rate of $3.27 \mathrm{~mm} \mathrm{yr}^{-1}$. The annual $\mathrm{ET}_{0}$ decreased both in LC and YC while increased slightly in TZ. Increasing rate of the annual $T_{\text {mean }}$ was

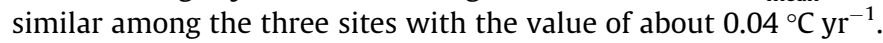

The main soil texture in the layer of $0-6.5 \mathrm{~m}, 6.5-10 \mathrm{~m}, 10-$ $12 \mathrm{~m}$, and $12-16 \mathrm{~m}$ at the LC site is silt loam, sandy loam, sand, 


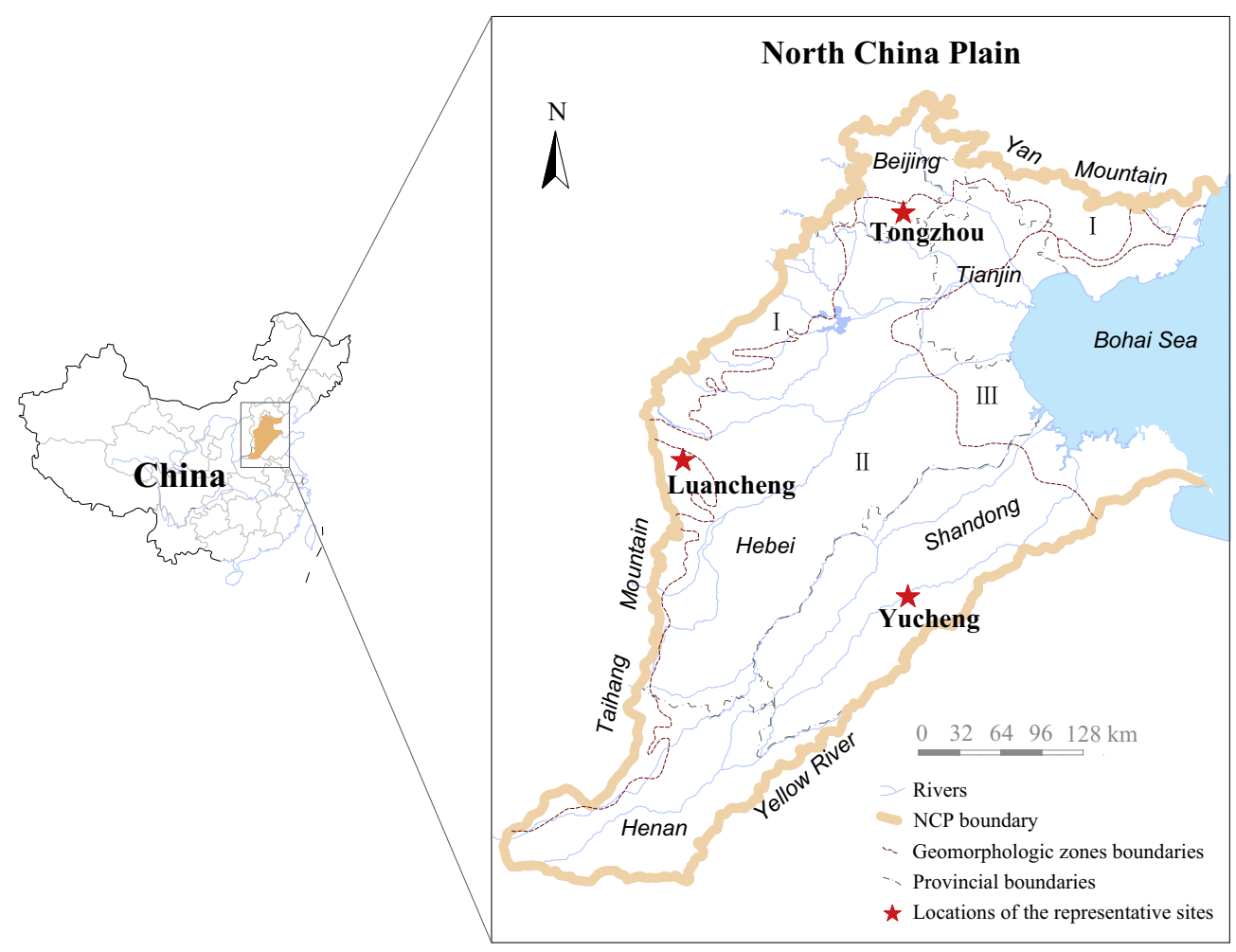

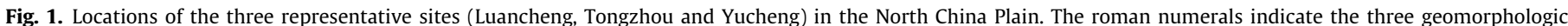
zones: piedmont plain (I), alluvial and lacustrine plains (II), and coastal plain (III).

and silt loam, respectively. The TZ site consists mainly of silt loam, sandy loam, sandy clay loam, and sand in the layer of 0-4 m, 47.1 $\mathrm{m}, 7.1-9.4 \mathrm{~m}$, and 9.4-13.2 m, respectively. The YC site is dominant with silt loam in the layer of $0-5 \mathrm{~m}$. The three sites are typical and representative of high agricultural production soils in the NCP. Because the depths of root water uptake were within $2 \mathrm{~m}$ for winter wheat and summer maize, the main soil physical properties within $2 \mathrm{~m}$ for $\mathrm{LC}$ and $\mathrm{TZ}$, and $5 \mathrm{~m}$ for YC were considered and presented in Table 1 . The measured soil profile could be divided into five, five and four layers in LC, TZ and YC, respectively. The soil texture at the three sites was dominant with silt loam. The clay contents in the lower soil layer were largest in LC (25.0\%) and least in $\mathrm{TZ}$ (1.9\%). Moreover, there were largest sandy contents (46.8\%) in the soil profile of the $\mathrm{TZ}$ site.

The daily variation of water table depth was significantly different among the three sites from 2000 to 2009 (Fig. 2). The water table depth at the LC site consistently decreased from $30.5 \mathrm{~m}$ to

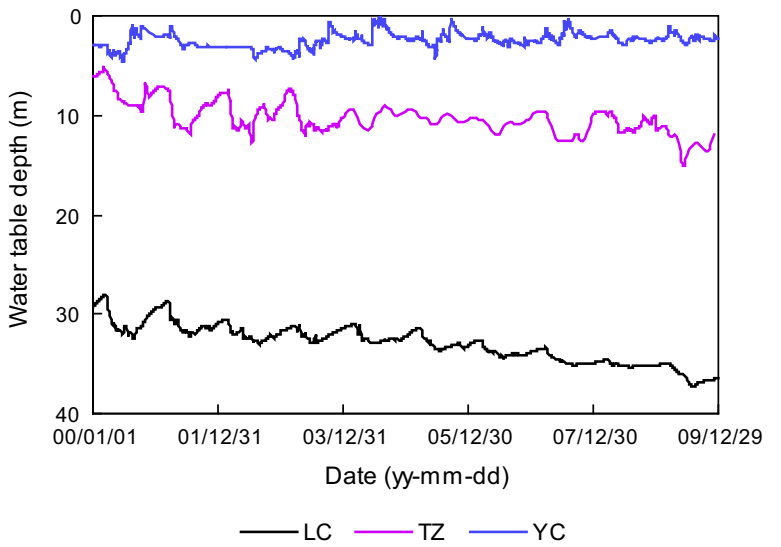

Fig. 2. Daily water table depth at the LC, TZ and YC sites from 2000 to 2009.

Table 1

Soil properties at the Luancheng (LC), Tongzhou (TZ) and Yucheng (YC) sites.

\begin{tabular}{|c|c|c|c|c|c|c|}
\hline Site & Soil depth $(\mathrm{cm})$ & Sand (\%) & Silt (\%) & Clay (\%) & Bulk density $\left(\mathrm{g} \mathrm{cm}^{-3}\right)$ & Soil texture \\
\hline \multirow[t]{5}{*}{ LC } & $0-20$ & 11.0 & 76.0 & 13.0 & 1.39 & Silt loam \\
\hline & $20-80$ & 10.0 & 78.0 & 12.0 & 1.48 & Silt loam \\
\hline & $80-120$ & 12.0 & 55.0 & 33.0 & 1.54 & Silt clay loam \\
\hline & $120-160$ & 15.0 & 60.0 & 25.0 & 1.63 & Silt loam \\
\hline & $160-200$ & 15.0 & 60.0 & 25.0 & 1.55 & Silt loam \\
\hline \multirow[t]{5}{*}{$\mathrm{TZ}$} & $0-40$ & 45.1 & 51.9 & 2.9 & 1.49 & Silt loam \\
\hline & $40-80$ & 37.2 & 60.4 & 2.4 & 1.53 & Silt loam \\
\hline & $80-120$ & 53.2 & 44.9 & 1.8 & 1.47 & Sandy loam \\
\hline & $120-150$ & 63.1 & 35.4 & 1.5 & 1.45 & Sandy loam \\
\hline & $150-200$ & 35.6 & 62.1 & 2.3 & 1.48 & Silt loam \\
\hline \multirow[t]{4}{*}{ YC } & $0-20$ & 12.9 & 65.1 & 22.1 & 1.27 & Silt loam \\
\hline & $20-60$ & 11.3 & 67.0 & 21.7 & 1.36 & Silt loam \\
\hline & $60-100$ & 28.3 & 58.0 & 13.7 & 1.40 & Silt loam \\
\hline & $100-500$ & 6.3 & 74.0 & 19.7 & 1.37 & Silt loam \\
\hline
\end{tabular}


$36.1 \mathrm{~m}$ below the soil surface with a rapid trend of $0.60 \mathrm{~m} \mathrm{yr}^{-1}$. At the $\mathrm{TZ}$ site, the water table depth decreased from $7.5 \mathrm{~m}$ to $12.6 \mathrm{~m}$ with a rate of $0.38 \mathrm{~m} \mathrm{yr}^{-1}$. In contrast, the water table depth fluctuated between 0 and $5 \mathrm{~m}$ in YC. The groundwater in YC was shallow because of interaction (infiltration and seepage) with the Yellow River, and recharge of precipitation and irrigation.

\section{Materials and methods}

\subsection{SWAP model}

In this study, the SWAP model was used to simulate one-dimensional vertical transient flow and crop response with considering the impacts of irrigation, rainfall, soil and water table depth (van Dam et al., 1997). The transient soil water flow in saturated-unsaturated zone is described by Richards' equation which is subsequently solved using an implicit finite-difference scheme:

$C(h) \frac{\partial h}{\partial t}=\frac{\partial}{\partial z}\left[K(h)\left(\frac{\partial h}{\partial z}+1\right)\right]-S_{a}(z)$

where $C$ is the differential soil water capacity $\left(\mathrm{cm}^{-1}\right), h$ is the soil water pressure head $(\mathrm{cm}), t$ is time (d), $z$ is the vertical coordinate $\left(\mathrm{cm}\right.$, positive upward), $K$ is the hydraulic conductivity $\left(\mathrm{cm} \mathrm{d}^{-1}\right)$, and $S_{a}$ is the soil water extraction rate by plant roots $\left(\mathrm{cm}^{3} \mathrm{~cm}^{-3} \mathrm{~d}^{-1}\right)$. The soil hydraulic functions are defined with the van Genuchten-Mualem model (van Genuchten et al., 1991):

$\theta(h)=\theta_{r}+\frac{\theta_{s}-\theta_{r}}{\left(1+|\alpha h|^{n}\right)^{(n-1) / n}}$

$K(\theta)=K_{s} S_{e}^{\lambda}\left[1-\left(1-S_{e}^{n /(n-1)}\right)^{(n-1) / n}\right]^{2}$

where $\theta_{r}$ is the residual water content $\left(\mathrm{cm}^{3} \mathrm{~cm}^{-3}\right), \theta_{s}$ is the saturated water content $\left(\mathrm{cm}^{3} \mathrm{~cm}^{-3}\right), \theta$ is the actual soil water content $\left(\mathrm{cm}^{3} \mathrm{~cm}^{-3}\right), \alpha\left(\mathrm{cm}^{-1}\right)$ and $n(-)$ are empirical shape factors, $K_{\mathrm{s}}$ is the saturated hydraulic conductivity $\left(\mathrm{cm} \mathrm{d}^{-1}\right), S_{e}=\left(\theta-\theta_{r}\right) /\left(\theta_{s}-\theta_{r}\right)$ is the relative saturation (-), and $\lambda$ is an empirical coefficient (-).

The simple crop growth module of Doorenbos and Kassam (1979) included in SWAP is used in this study. Crop growth is described by the leaf area index (LAI), crop height $(\mathrm{CH})$ and rooting depth (RD) as a function of development stage (DVS). The DVS is assumed to be linear with growth time from emergence to harvest $(0<$ DVS $<2)$.

\subsection{Model setup at the three representative sites}

A few field experiments have been conducted at the LC, TZ and YC sites to investigate water movement and crop response under different irrigation practices for winter wheat and summer maize. Field experiments with two rotations carried out at the LC (from 1998 to 2000), TZ (from 2007 to 2009), and YC site (from 2001 to 2003) were used for the SWAP model evaluation in this study (Table 2). The detailed measurements and results at the LC, TZ and YC sites were demonstrated by Zhang et al. (2004), Ma et al. (2011) and Fang et al. (2007), respectively. The SWAP model was setup at the three sites, which was described in detail in the following.

According to the water table depth range at the three sites, the simulated soil profile was set to be $200 \mathrm{~cm}$ depth for both the LC and TZ sites, and $500 \mathrm{~cm}$ depth for the YC site. The simulated soil profile was vertically discretized into 45,49 and 55 compartments in the LC, TZ and YC sites, respectively. To ensure the convergence of the numerical solution, thinner compartments were used at the surface soil layer where rapid changes in water content and pressure head gradients often occurred. A 1-day time step was used in the modeling.

The upper boundary condition is determined by the potential evapotranspiration rate, and irrigation and precipitation fluxes. The potential evapotranspiration rate is estimated by the Penman-Monteith equation. To define the upper boundary condition, the daily meteorological data in LC (1998-2000) and YC (2001-2003) were both obtained from the Chinese Ecosystem Research Network (http://www.cerndata.ac.cn/) to estimate the potential evapotranspiration, while those data in TZ (2007-2009) were collected at the local meteorological station.

For the lower boundary condition, the free drainage condition was implemented at the LC and TZ sites as the water table was deep. In this case, unit pressure head gradient was assumed at the bottom boundary. In YC, the free water level $(0.09-4.60 \mathrm{~m})$

Table 2

The irrigation amount for winter wheat and summer maize in experimental seasons at the LC, TZ and YC sites.

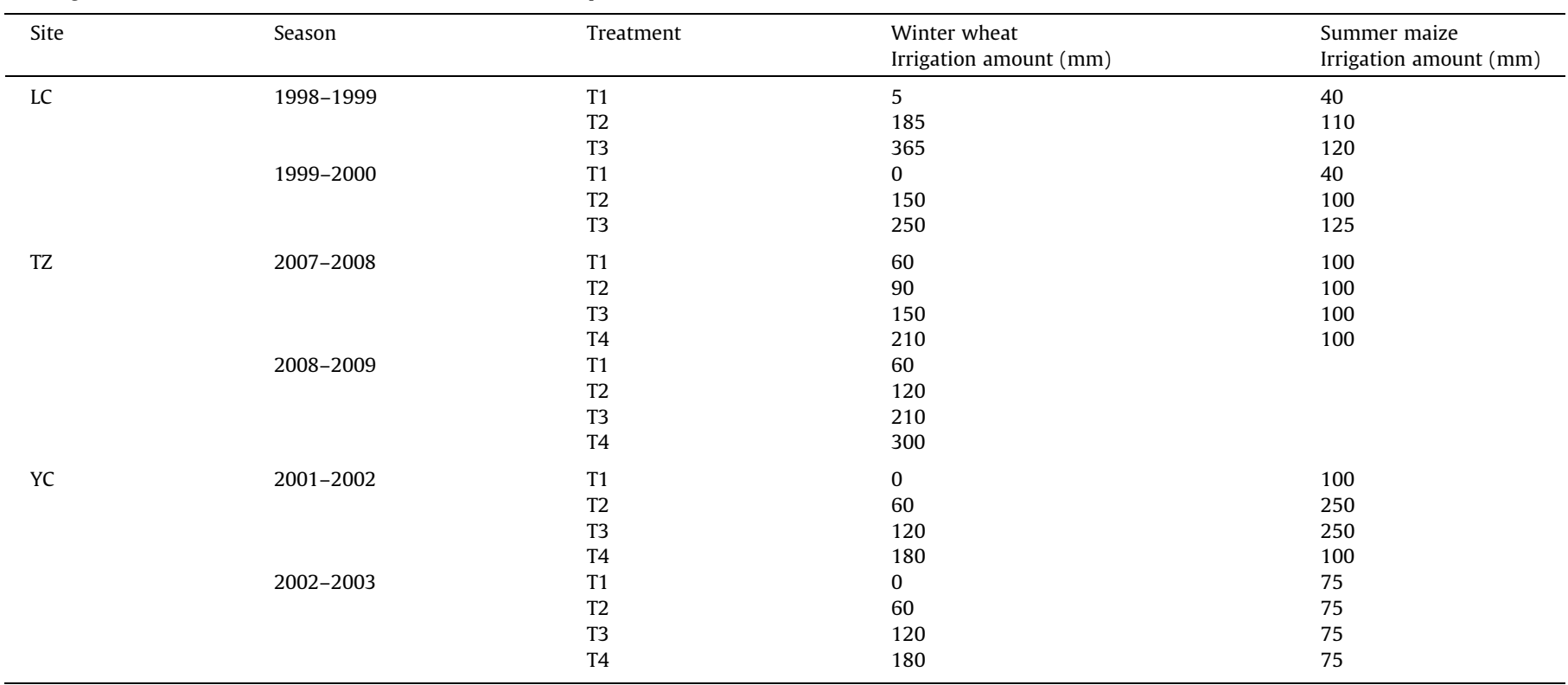


located within the simulated profile and the Dirichlet type (given pressure head) lower boundary was used. The bottom boundary pressure head value of soil profile could be determined according to the daily water table depth as follows:

$h=G W L-z-h_{\text {resis }}$

where $h$ is the pressure head at the bottom of the soil profile $(\mathrm{cm})$, $G W L$ is the groundwater level (negative = below surface level, $\mathrm{cm}$ ), $z$ is the position of bottom nodal point (negative, $\mathrm{cm}$ ), $h_{\text {resis }}$ is the head difference between the groundwater level and hydraulic head of the bottom nodal point in the previous time step.

The initial soil moisture measured from the field experiments was used to determine the initial conditions of pressure head at each compartment of soil profile in LC and TZ. In YC, the initial moisture conditions as an equilibrium profile with the groundwater table were defined. In this case, the nodal pressure head at the groundwater level equaled zero and the nodal pressure head decreased linearly with height toward the soil surface.

The vegetation parameters including the $\mathrm{LAI}$ and $\mathrm{CH}$ at different crop development stages, length of crop cycle, and maximum rooting depth were measured at each site (Zhang et al., 2004; Ma et al., 2011; Fang et al., 2007). The initial crop parameters including the extinction coefficient for diffuse and direct visible light, minimum canopy resistance, limiting pressure heads, and salinity were set to the values recommended by van Dam et al. (1997). The minimum volumetric soil air content in the top $25 \mathrm{~cm}$ of loam soil was 0.08 . Then they were adjusted manually using the crop measurements at each site. The input parameters used for the simulated crop (winter wheat and summer maize) at the three sites were summarized in Table 3.

\subsection{Model calibration and validation}

For model calibration, the initial soil hydraulic parameters were estimated by fitting the measured soil textural percentages and bulk density to the van Genuchten-Mualem equations with the Rosetta pedotransfer functions of Schaap et al. (1998). The calibration was carried out with soil moisture data of the T1 and T3 treatments in LC, and the $\mathrm{T} 1$ and $\mathrm{T} 4$ treatments in both $\mathrm{TZ}$ and $\mathrm{YC}$ (Table 2). The van Genuchten-Mualem parameters ( $n$ and $\alpha$ ) were first adjusted using the PEST package, which has unique nonlinear parameter estimation capability (Doherty, 2002). When the differences between simulated and measured soil water contents were larger than the standard deviation, other three parameters were also optimized. After calibration, soil moisture data from the remaining treatments ( $\mathrm{T} 2$ treatment in $\mathrm{LC}, \mathrm{T} 2$ and $\mathrm{T} 3$ treatments in TZ and YC) (Table 2) were used for model validation. Two quantitative performance criteria including root mean square error (RMSE) and Nash-Sutcliffe model efficiency (NSME) were used to quantify the deviation of the modeling results from the observed data.

\subsection{Model application}

The validated SWAP model was applied to search optimal irrigation scheduling and estimate groundwater recharge at the three sites in different hydrological years during 1961-2009.

\subsubsection{Determination of hydrological years}

Rainfall frequencies during the whole year, winter wheat season and summer maize season were analyzed using the log-Pearson III type distribution method to determine the hydrological years at the three sites. The long sequences of climate data at the three sites were obtained from the local Meteorological Administration Bureau. The results showed that precipitation at $25 \%, 50 \%$, and $75 \%$ precipitation exceedance probabilities (PEPs) for the whole year was 630,510 , and $400 \mathrm{~mm}$ for the LC site, 680,540 , and $420 \mathrm{~mm}$ for the TZ site, and 670,532 , and $420 \mathrm{~mm}$ for the YC site, respectively. In this study, we chose the most typical hydrologic years with the same PEPs for the whole year and two crop seasons, which were commonly used in previous studies to determine hydrological years. The typical year for $25 \%, 50 \%$, and 75\% PEP was 1987-1988, 1984-1985, and 2005-2006 in LC, 19771978,1991-1992, and 1980-1981 in TZ, 1993-1994,1978-1979, and 2005-2006 in YC, respectively.

\subsubsection{Design of irrigation scenarios}

The irrigation scheduling scenarios of winter wheat and summer maize were designed according to previous experimental data and literatures in the NCP (Zhang et al., 2003, 2006; Shang et al., 2009; Li et al., 2005). Moreover, the differences of the precipitation amount at each crop season among the three sites were also considered for designing irrigation scenarios. The amount of each irrigation was recommended to be $60-80 \mathrm{~mm}$ in the NCP. As the water deficit in winter wheat season increased in turn at the TZ, LC and YC sites, each irrigation amount of 75, 70 and $60 \mathrm{~mm}$ was correspondingly set for the three sites. During the summer maize season, $60 \mathrm{~mm}$ of irrigation water was applied each time at the three sites. The timing of irrigation was designed to roughly match the key development stages of wheat and maize. The reference

Table 3

Main crop parameters specified for SWAP model at the LC, TZ and YC sites.

\begin{tabular}{|c|c|c|c|c|c|c|}
\hline \multirow[t]{2}{*}{ Parameter } & \multicolumn{2}{|l|}{ LC } & \multicolumn{2}{|l|}{$\mathrm{TZ}$} & \multicolumn{2}{|l|}{ YC } \\
\hline & Winter wheat & Summer maize & Winter wheat & Summer maize & Winter wheat & Summer maize \\
\hline Length of crop cycle (d) & 244 & 96 & 252 & 93 & 236 & 103 \\
\hline Extinction coefficient for diffuse visible light, $\kappa_{\text {dif }}(-)$ & 0.7 & 0.55 & 0.65 & 0.6 & 0.6 & 0.5 \\
\hline Extinction coefficient for direct visible light, $\kappa_{\mathrm{dir}}(-)$ & 0.9 & 0.75 & 1.0 & 0.75 & 0.9 & 0.75 \\
\hline Maximum rooting depth $(\mathrm{cm})$ & 105 & 65 & 100 & 60 & 100 & 80 \\
\hline Minimum canopy resistance, $r_{\text {crop }}\left(\mathrm{sm}^{-1}\right)$ & 65 & 70 & 50 & 70 & 55 & 80 \\
\hline \multicolumn{7}{|l|}{ Limiting pressure heads, $h(\mathrm{~cm})$} \\
\hline$h_{1}$ & -0.1 & -15 & -0.1 & -15 & -0.1 & -15 \\
\hline$h_{2}$ & -1.0 & -30 & -1.0 & -30 & -1.0 & -30 \\
\hline$h_{3}^{h}$ & -400 & -325 & -500 & -350 & -300 & -400 \\
\hline$h_{3}^{l}$ & -1200 & -600 & -900 & -700 & -800 & -650 \\
\hline$h_{4}$ & -8500 & -8000 & $-16,000$ & $-14,000$ & $-11,000$ & -9000 \\
\hline \multicolumn{7}{|l|}{ Salinity } \\
\hline Critical level, $E C_{\max }\left(\mathrm{dSm}^{-1}\right)$ & 6.0 & 1.8 & 6.0 & 1.8 & 6.0 & 1.8 \\
\hline Decline per unit $\mathrm{EC}, E C_{\text {slope }}\left(\% \mathrm{dSm}^{-1}\right)$ & 7.1 & 7.4 & 7.1 & 7.4 & 7.1 & 7.4 \\
\hline
\end{tabular}


Table 4

Irrigation scenarios of winter wheat and summer maize for searching the optimal irrigation scheduling at the LC, TZ and YC sites.

\begin{tabular}{|c|c|c|c|c|c|c|c|c|c|c|}
\hline \multirow[t]{2}{*}{ Site } & \multirow[t]{2}{*}{ Scenario } & \multicolumn{5}{|l|}{ Winter wheat } & \multicolumn{4}{|c|}{$\underline{\text { Summer maize }}$} \\
\hline & & $\begin{array}{l}\text { Winter-dormancy } \\
(\mathrm{mm})\end{array}$ & $\begin{array}{l}\text { Greening } \\
(\mathrm{mm})\end{array}$ & $\begin{array}{l}\text { Jointing } \\
(\mathrm{mm})\end{array}$ & $\begin{array}{l}\text { Heading } \\
(\mathrm{mm})\end{array}$ & $\begin{array}{l}\text { Filling } \\
(\mathrm{mm})\end{array}$ & $\begin{array}{l}\text { Pre-sowing } \\
(\mathrm{mm})\end{array}$ & $\begin{array}{l}\text { Jointing } \\
(\mathrm{mm})\end{array}$ & $\begin{array}{l}\text { Heading } \\
(\mathrm{mm})\end{array}$ & $\begin{array}{l}\text { Filling } \\
(\mathrm{mm})\end{array}$ \\
\hline \multirow[t]{5}{*}{ LC } & S1 & - & - & - & 70 & - & 60 & - & - & - \\
\hline & S2 & - & - & 70 & 70 & - & 60 & - & 60 & - \\
\hline & S3 & - & 70 & 70 & 70 & - & 60 & - & 60 & 60 \\
\hline & $\mathrm{S} 4$ & - & 70 & 70 & 70 & 70 & 60 & 60 & 60 & 60 \\
\hline & S5 & 70 & 70 & 70 & 70 & 70 & 60 & 60 & 60 & 60 \\
\hline \multirow[t]{5}{*}{$\mathrm{TZ}$} & $\mathrm{S} 1$ & 75 & - & - & - & - & - & - & - & - \\
\hline & S2 & 75 & - & - & 75 & - & 60 & - & - & - \\
\hline & S3 & 75 & - & 75 & 75 & - & 60 & - & 60 & - \\
\hline & S4 & 75 & - & 75 & 75 & 75 & 60 & - & 60 & 60 \\
\hline & S5 & 75 & 75 & 75 & 75 & 75 & 60 & 60 & 60 & 60 \\
\hline \multirow[t]{5}{*}{ YC } & $\mathrm{S} 1$ & - & - & - & 60 & - & 60 & - & - & - \\
\hline & $\mathrm{S} 2$ & - & - & 60 & 60 & - & 60 & - & 60 & - \\
\hline & S3 & - & 60 & 60 & 60 & - & 60 & - & 60 & 60 \\
\hline & S4 & - & 60 & 60 & 60 & 60 & 60 & 60 & 60 & 60 \\
\hline & S5 & 60 & 60 & 60 & 60 & 60 & 60 & 60 & 60 & 60 \\
\hline
\end{tabular}

Note: “-” shows no irrigation applied.

irrigation scheduling was defined with 5 irrigation times (at the stages of winter dormancy, greening, jointing, heading and filling) for winter wheat and 4 irrigation times (at the stages of pre-sowing, jointing, heading and filling) for summer maize at the three sites, which could sufficiently meet the water requirements during the full growing season (Zhang et al., 2006). According to the above principles, five irrigation scenarios were designed for each hydrological year at every site (Table 4). Scenario 5 (S5) in Table 4 represented the reference irrigation scenario.

\subsubsection{Determination of optimal irrigation scheduling and groundwater} recharge

The optimal irrigation scheduling and groundwater recharge of the different hydrological years at the three sites were simulated with the validated crop and soil parameters. The initial condition for each soil compartment in LC and TZ was defined as the nodal pressure heads corresponding to 0.7 times of the field capacity (Shang et al., 2009). An equilibrium profile of pressure head with the water table was specified at the sowing date of winter wheat in YC. The water tables of the specific hydrological years in YC were obtained from the Chinese Ecosystem Research Network.

The water use efficiency (WUE) was generally used to search optimal irrigation scheduling. However, only the relative yield could be obtained by the simple crop model in SWAP. Therefore, the relative water use efficiency $\left(W_{U} E_{r}\right)$ was introduced to compare each irrigation scenario with the reference irrigation scenario. The $\mathrm{WUE}_{r}$ for the ith irrigation scenario $\left(\mathrm{WUE}_{r}^{i}\right.$ ) was calculated as:

$\mathrm{WUE}_{r}^{i}=\frac{\mathrm{WUE}^{i}}{\mathrm{WUE}^{t}}=\frac{\mathrm{Y}_{r}^{i} \mathrm{Y}_{p} / \mathrm{ET}^{i}}{\mathrm{Y}_{r}^{t} \mathrm{Y}_{p} / \mathrm{ET}^{t}}=\frac{\mathrm{Y}_{r}^{i}}{\mathrm{Y}_{r}^{t}} \frac{\mathrm{ET}^{t}}{\mathrm{ET}^{i}}$

where the superscript $i$ and $t$ indicated the $i$ th and reference irrigation scenario, respectively, $\mathrm{Y}_{r}$ was the relative yield, $\mathrm{Y}_{p}$ was the potential yield under sufficient irrigation, ET was the actual evapotranspiration. This indicator could clearly show the advantages of the optimal irrigation scheduling with respect to other scenarios. The highest $\mathrm{WUE}_{r}$ was used as the principal evaluation criterion of the optimal irrigation scheduling at different hydrological years.

Meanwhile, the water balance components including soil water storage change $(\Delta W)$ and actual evapotranspiration (ET) were also determined under different irrigation scenarios. The simulated drainage at the bottom of the soil profile in YC and TZ and that at the groundwater level in YC was assumed to be the groundwater recharge $(R)$ at each site.

\section{Results}

\subsection{Model evaluation}

The optimized hydraulic parameters from the calibration procedure were shown in Table 5. As typical examples, Fig. 3 showed the

Table 5

Calibrated soil hydraulic parameters in the SWAP model at the LC, TZ and YC sites.

\begin{tabular}{|c|c|c|c|c|c|c|c|}
\hline Site & Soil depth $(\mathrm{cm})$ & $\theta_{r}\left(\mathrm{~cm}^{3} \mathrm{~cm}^{-3}\right)$ & $\theta_{s}\left(\mathrm{~cm}^{3} \mathrm{~cm}^{-3}\right)$ & $K_{s}\left(\mathrm{~cm} \mathrm{~d}^{-1}\right)$ & $\alpha\left(\mathrm{cm}^{-1}\right)$ & $\lambda(-)$ & $n(-)$ \\
\hline \multirow[t]{5}{*}{ LC } & $0-20$ & 0.01 & 0.49 & 100.0 & 0.0500 & -0.8 & 1.18 \\
\hline & $20-80$ & 0.02 & 0.47 & 58.0 & 0.0250 & -2.3 & 1.20 \\
\hline & $80-120$ & 0.02 & 0.46 & 2.0 & 0.0200 & -3.0 & 1.14 \\
\hline & $120-160$ & 0.03 & 0.42 & 0.3 & 0.0300 & -3.5 & 1.15 \\
\hline & $160-200$ & 0.01 & 0.44 & 1.6 & 0.0200 & -2.0 & 1.08 \\
\hline \multirow[t]{5}{*}{$\mathrm{TZ}$} & $0-40$ & 0.10 & 0.41 & 18.1 & 0.0025 & 0.5 & 1.90 \\
\hline & $40-80$ & 0.06 & 0.42 & 14.8 & 0.0040 & 0.5 & 1.41 \\
\hline & $80-120$ & 0.10 & 0.40 & 20.8 & 0.0096 & 0.5 & 1.49 \\
\hline & $120-150$ & 0.08 & 0.41 & 22.9 & 0.0110 & 0.5 & 1.46 \\
\hline & $150-200$ & 0.05 & 0.43 & 10.1 & 0.0105 & 0.5 & 1.34 \\
\hline \multirow[t]{4}{*}{ YC } & $0-20$ & 0.02 & 0.32 & 154.0 & 0.0120 & 0.3 & 1.30 \\
\hline & $20-60$ & 0.12 & 0.37 & 60.6 & 0.0235 & 0.3 & 1.31 \\
\hline & $60-100$ & 0.13 & 0.42 & 22.6 & 0.0308 & 0.7 & 1.30 \\
\hline & $100-500$ & 0.14 & 0.45 & 15.7 & 0.0411 & 0.9 & 1.28 \\
\hline
\end{tabular}


(a)
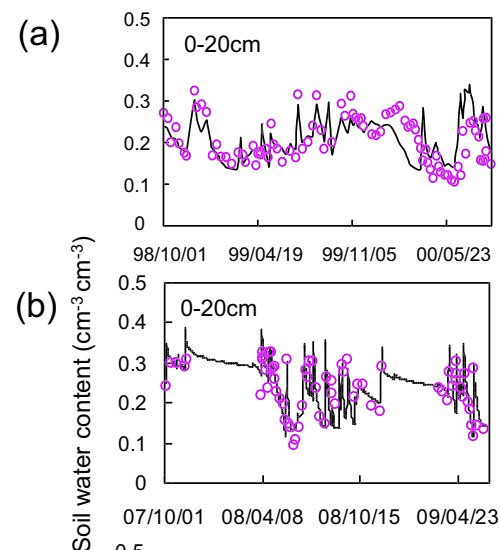

(c)

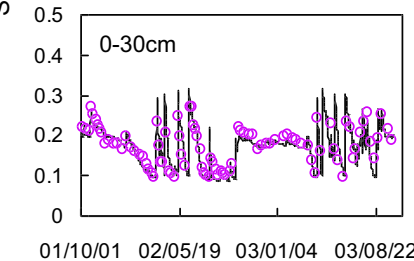

01/10/01 02/05/19 03/01/04 03/08/22

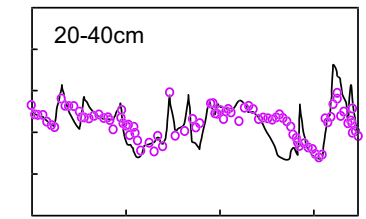

98/10/01 99/04/19 99/11/05 00/05/23

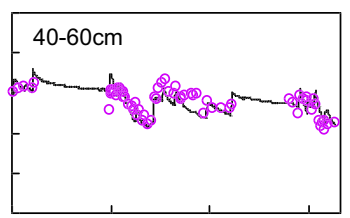

07/10/01 08/04/08 08/10/15 09/04/23

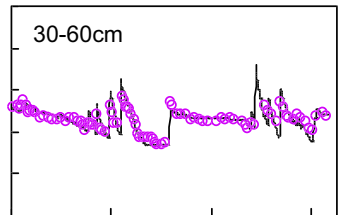

01/10/01 02/05/19 03/01/04 03/08/22

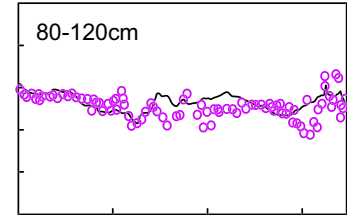

98/10/01 99/04/19 99/11/05 00/05/23

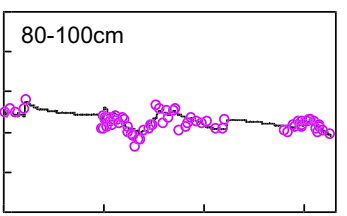

07/10/01 08/04/08 08/10/15 09/04/23

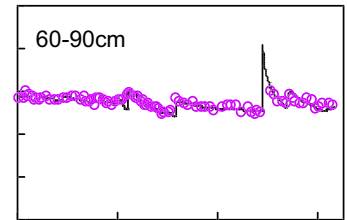

01/10/01 02/05/19 03/01/04 03/08/22 Date $(\mathrm{yy} / \mathrm{mm} / \mathrm{dd})$

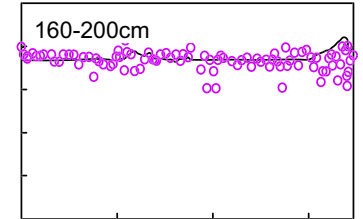

98/10/01 99/04/19 99/11/05 00/05/23

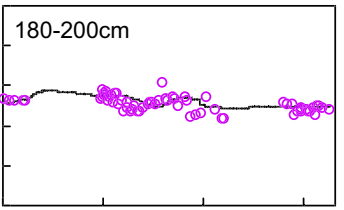

07/10/01 08/04/08 08/10/15 09/04/23

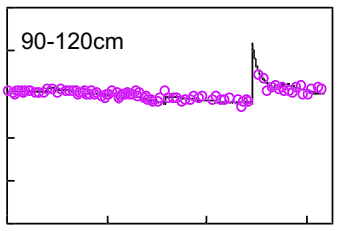

$\begin{array}{llll}01 / 10 / 01 & 02 / 05 / 19 & 03 / 01 / 04 & 03 / 08 / 22\end{array}$

C Simulated $\circ$ Measured

Fig. 3. Comparison between measured and simulated soil water contents of different depths at the (a) LC, (b) TZ and (c) YC sites.

observed and simulated soil water contents of T3 (in LC) and T4 (in $\mathrm{TZ}$ and $\mathrm{YC}$ ) during the experimental seasons at the three sites. It could be found that the simulated soil water contents agreed well with the observed values. Furthermore, the average RMSE was $0.047,0.022$ and $0.013 \mathrm{~cm}^{3} \mathrm{~cm}^{-3}$ for the LC, TZ and YC site, respectively. The total variability of measured soil water content was $16.53 \%, 14.63 \%$, and $12.84 \%$ for the LC, TZ, and YC site, respectively. The average NSME was $0.70,0.77$ and 0.74 for the LC, TZ and YC site, respectively. All the NMSE values were higher than 0.70 .

To compare the simulated and observed crop yields of different treatments during the experimental years, the simulated crop yield was derived by the product of the relative crop yield and the crop yield of the treatment with sufficient irrigation. Fig. 4 showed that the simulated grain yields of winter wheat and summer maize matched well with the measured ones. The RMSE values of grain yield simulation for winter wheat and summer maize were $349.15 \mathrm{~kg} \mathrm{hm}^{-2}$ and $88.40 \mathrm{~kg} \mathrm{hm}^{-2}$ in LC, $390.54 \mathrm{~kg} \mathrm{hm}^{-2}$ and $225.77 \mathrm{~kg} \mathrm{hm}^{-2}$ in TZ, $315.24 \mathrm{~kg} \mathrm{hm}^{-2}$ and $327.17 \mathrm{~kg} \mathrm{hm}^{-2}$ in YC, respectively. The NSME values for winter wheat and summer maize were 0.85 and 0.80 in LC, 0.83 and 0.76 in TZ, 0.83 and 0.81 in YC, respectively.

The above model evaluation results indicated that the SWAP with calibrated parameters could be applied to evaluate field water balance and crop response for the local crop rotation of winter wheat and summer maize. It could be used as an irrigation management tool to evaluate the optimal irrigation scheduling and groundwater recharge.

\subsection{Comparison of optimal irrigation scheduling among the three sites}

Table 6 showed the $\mathrm{WUE}_{r}$ for winter wheat and summer maize under different irrigation scenarios with 25\%, 50\% and 75\% PEPs at the LC, TZ and YC sites. The optimal irrigation scenario at 25\%, 50\% and 75\% PEP was S1, S2 and S3 in LC, S2, S3 and S4 in TZ, and S1, S2 and S2 in YC, respectively (Table 6).

The optimal irrigation amount for winter wheat at 25\%,50\% and $75 \%$ PEPs was 70, 140 and $210 \mathrm{~mm}$ at the LC site, respectively. The irrigation times were one at heading stage, two at jointing and heading stages, and three at greening, jointing and heading stages for $25 \%, 50 \%$ and $75 \%$ PEPs in this area, respectively. For summer maize, the optimal irrigation amount at 25\%, 50\% and 75\% PEPs was 60,120 and $180 \mathrm{~mm}$, respectively. The irrigation at pre-sowing stage was applied at $25 \% \mathrm{PEP}$, whereas one more irrigation at heading stage and two more irrigations at heading and filling stages were required at $50 \%$ and $75 \%$ PEPs, respectively. The water use efficiency of optimal irrigation scheduling for winter wheat was improved by $23 \%$ on average compared to the reference irrigation scheduling. The $\mathrm{WUE}_{r}$ of the optimal irrigation scenario for summer maize was 1.12 and 1.04 at the 25\% and 50\% PEPs in $\mathrm{LC}$, respectively. These $\mathrm{WUE}_{r}$ values were within the range between 0.94 and 1.27 obtained by Zhang et al. (2006) from field experiments during 1997-2005.

For the TZ site, the optimal irrigation amount for winter wheat at $25 \%, 50 \%$ and $75 \%$ PEPs was 150,225 and $300 \mathrm{~mm}$, while the amount for summer maize at the corresponding year was 60,120 and $180 \mathrm{~mm}$, respectively. The optimal irrigation times were specified at winter-dormancy and heading stages for winter wheat, and pre-sowing stage for summer maize at 25\% PEP. Additional irrigation was needed for winter wheat at jointing stage and at heading stage for summer maize at 50\% PEP. The best choice of irrigation time in 75\% PEP was applied at winter-dormancy, jointing, heading and filling stages for winter wheat, and at pre-sowing, heading and filling stages for summer maize.

As shown in Table 6, the optimal irrigation scheduling at 25\% PEP in YC was one irrigation of $60 \mathrm{~mm}$ at heading stage for winter wheat and one irrigation of $60 \mathrm{~mm}$ at pre-sowing stage for summer maize. While at 50\% PEP, the optimal irrigation amounts was $120 \mathrm{~mm}$ for both winter wheat and summer maize. The corresponding irrigation time was two at jointing and heading stages for winter wheat, and two at pre-sowing and heading stages for summer maize. The optimal irrigation scheduling at $75 \%$ PEP was same to that at 50\% PEP. This may be due to that the water table at the $75 \%$ PEP (an average of $2.24 \mathrm{~m}$ ) was shallower than that at $50 \%$ PEP (an average of $3.03 \mathrm{~m}$ ). The groundwater contribution to crop water consumption compensated the negative effects of smaller rainfall at $75 \%$ PEP. 

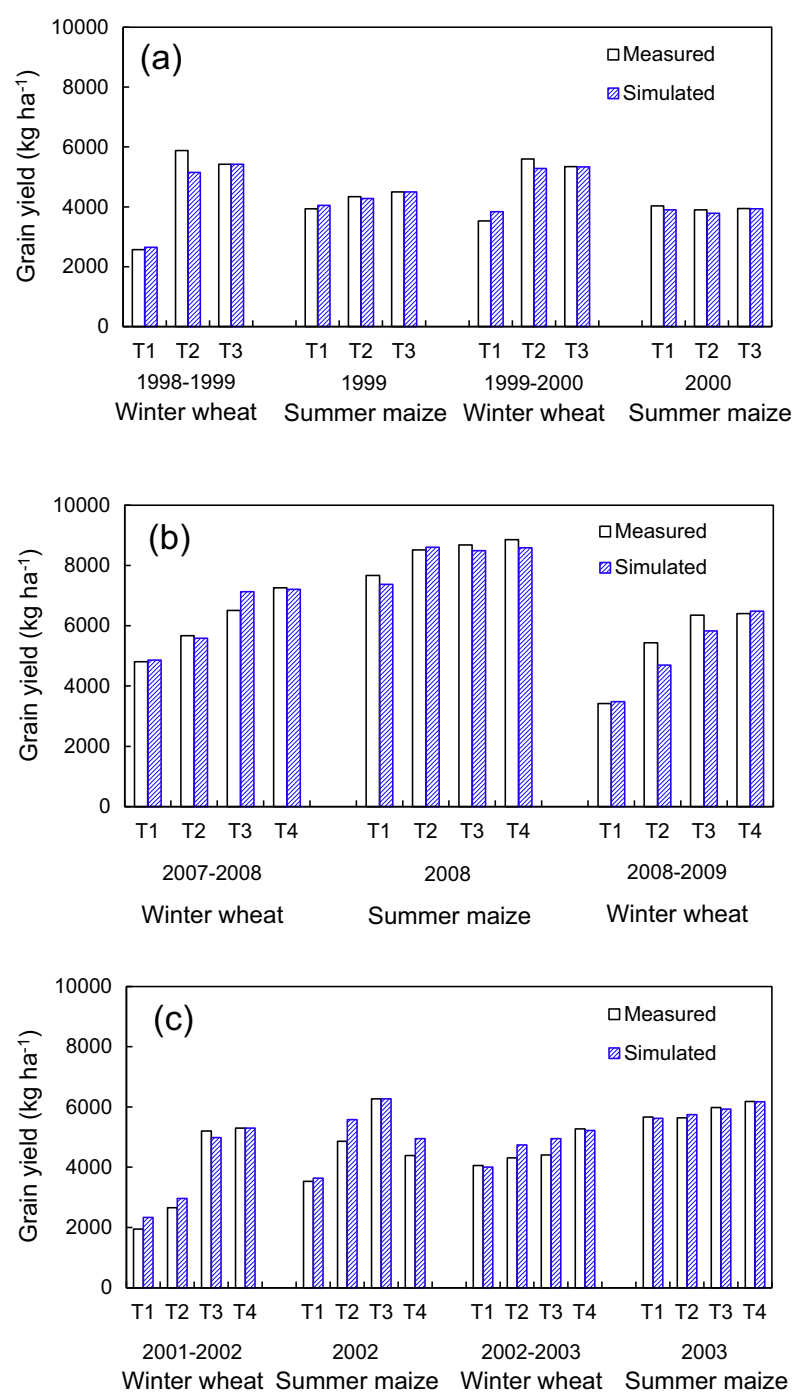

Fig. 4. Comparison between measured and simulated grain yield of different treatments for winter wheat and summer maize in experimental seasons at the (a) LC, (b) TZ and (c) YC sites. The simulated grain yield was derived by the product of the relative crop yield and the actual crop yield of the sufficient irrigation treatment.
Comparison of the optimal irrigation schedulings among the three sites indicated that the largest irrigation amount for winter wheat was needed for the TZ site whereas the amount was least for the YC site at each hydrologic year. The optimal irrigation times in winter wheat season were same for the LC and YC sites at 25\% and 50\% PEPs. However, additional irrigation at greening stage for winter wheat was specified at the LC site with respect to the YC site at 75\% PEP. Compared to the LC and YC sites, additional irrigation at winter-dormancy stage was necessary for the TZ site at each hydrologic year. Furthermore, irrigation at filling stage was needed for the TZ site at 75\% PEP. For summer maize, the optimal irrigation amounts and times were same among the three sites at $25 \%$ and $50 \%$ PEPs. At $75 \%$ PEP, irrigation was needed at filling stage in $\mathrm{LC}$ and $\mathrm{TZ}$ and this irrigation was not required in YC (S3 for the LC site, S4 for the TZ site, and S2 for the YC site in Tables 4 and 6).

\subsection{Comparison of evapotranspiration and groundwater recharge among the three sites}

The water balance components during winter wheat-summer maize growth period for optimal and reference irrigation scheduling at the three sites were given in Table 7. The variations of cumulative ET and $R$ were presented in Figs. 5-7 for the LC, TZ, and YC site, respectively.

The $\Delta W$ and ET during the rotation period under optimal irrigation scheduling reduced compared to the reference irrigation scheduling. The reduction values were 112.0 and $141.0 \mathrm{~mm}$ in LC, 23.1 and $44.3 \mathrm{~mm}$ in TZ, and 65.7 and $88.5 \mathrm{~mm}$ in YC, respectively. This result indicated that using the optimal irrigation scheduling could make the best of soil water storage at the three sites, which was critical for growth of winter wheat. The reduction of cumulative ET under optimal irrigation with respect to reference irrigation increased with growth time from greening to harvest during winter wheat season in both LC and YC. This reduction was not evident in TZ, especially at 75\% PEP. There was little difference between cumulative ET during summer maize season under optimal and reference irrigation schedulings for most of PEPs at the three sites. However, the total ET of optimal irrigation scheduling increased by about $45 \mathrm{~mm}$ at 25\% PEP with respect to reference irrigation scheduling in LC. The water logging caused by combination of heavy rainfall and irrigation at the heading stage under reference irrigation scheduling restricted the root water uptake, which resulted in the significant decrease of actual evapotranspiration at $25 \%$ PEP.

Table 6

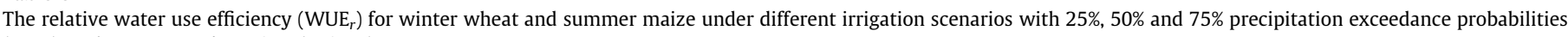
(PEPs) at the LC, TZ and YC sites (unit: -).

\begin{tabular}{|c|c|c|c|c|c|c|c|}
\hline \multirow[t]{2}{*}{ Site } & \multirow[t]{2}{*}{ Treatment } & \multicolumn{2}{|l|}{ 25\% PEP } & \multicolumn{2}{|l|}{$50 \%$ PEP } & \multicolumn{2}{|l|}{ 75\% PEP } \\
\hline & & Winter wheat & Summer maize & Winter wheat & Summer maize & Winter wheat & Summer maize \\
\hline \multirow[t]{5}{*}{ LC } & $\mathrm{S} 1$ & 1.39 & 4.89 & 1.15 & 0.97 & 1.00 & 0.91 \\
\hline & S2 & 1.22 & 4.69 & 1.21 & 1.12 & 1.02 & 1.03 \\
\hline & S3 & 1.11 & 4.37 & 1.16 & 1.07 & 1.08 & 1.04 \\
\hline & S4 & 1.03 & 2.99 & 1.04 & 1.06 & 1.00 & 1.00 \\
\hline & S5 & 1.00 & 1.00 & 1.00 & 1.00 & 1.00 & 1.00 \\
\hline \multirow[t]{5}{*}{$\mathrm{TZ}$} & $\mathrm{S} 1$ & 1.02 & 1.00 & 0.98 & 0.95 & 0.94 & 0.95 \\
\hline & $\mathrm{S} 2$ & 1.03 & 1.01 & 1.02 & 0.98 & 0.97 & 0.97 \\
\hline & S3 & 1.01 & 0.99 & 1.04 & 1.00 & 1.00 & 0.98 \\
\hline & $\mathrm{S} 4$ & 1.01 & 0.99 & 1.02 & 0.98 & 1.02 & 1.01 \\
\hline & S5 & 1.00 & 1.00 & 1.00 & 1.00 & 1.00 & 1.00 \\
\hline \multirow[t]{5}{*}{ YC } & S1 & 1.17 & 1.06 & 1.02 & 0.97 & 1.06 & 0.63 \\
\hline & $\mathrm{S} 2$ & 1.11 & 1.03 & 1.06 & 1.06 & 1.08 & 1.06 \\
\hline & S3 & 1.06 & 1.00 & 1.02 & 1.02 & 1.04 & 1.05 \\
\hline & S4 & 1.01 & 1.00 & 1.01 & 1.00 & 1.03 & 1.00 \\
\hline & S5 & 1.00 & 1.00 & 1.00 & 1.00 & 1.00 & 1.00 \\
\hline
\end{tabular}


Table 7

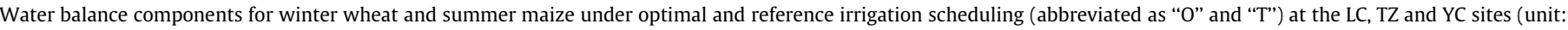
$\mathrm{mm})$.

\begin{tabular}{|c|c|c|c|c|c|c|c|c|c|c|c|c|c|c|c|}
\hline \multirow[t]{2}{*}{ Site } & \multirow[t]{2}{*}{ PEP (\%) } & \multirow{2}{*}{$\begin{array}{l}\text { Irrigation } \\
\text { scheduling }\end{array}$} & \multicolumn{6}{|c|}{ Winter wheat } & \multicolumn{6}{|c|}{ Summer maize } & \multirow{2}{*}{$\begin{array}{l}\text { Total irrigation } \\
\text { amount }\end{array}$} \\
\hline & & & $I$ & $P$ & $P_{i}$ & $\Delta W$ & ET & $R$ & $I$ & $P$ & $P_{i}$ & $\Delta W$ & ET & $R$ & \\
\hline \multirow[t]{6}{*}{ LC } & \multirow[t]{2}{*}{25} & 0 & 70 & 193.8 & 8.3 & -72.3 & 327.5 & 0.3 & 60 & 490.8 & 15.1 & 186.9 & 348.7 & 0.1 & 130 \\
\hline & & $\mathrm{T}$ & 350 & 193.8 & 8.3 & -8.6 & 543.9 & 0.2 & 240 & 490.8 & 15.1 & 193.5 & 293.3 & 228.9 & 590 \\
\hline & \multirow{2}{*}{50} & 0 & 140 & 130.7 & 10.6 & -94.8 & 354.6 & 0.3 & 120 & 386.1 & 15.9 & 128.5 & 361.6 & 0.1 & 260 \\
\hline & & $\mathrm{T}$ & 350 & 130.7 & 10.6 & -47.7 & 517.5 & 0.3 & 240 & 386.1 & 15.9 & 248.1 & 362.0 & 0.1 & 590 \\
\hline & \multirow[t]{2}{*}{75} & 0 & 210 & 100.6 & 10.6 & -90.5 & 390.3 & 0.2 & 180 & 286.1 & 8.2 & 129.3 & 328.5 & 0.1 & 390 \\
\hline & & $\mathrm{T}$ & 350 & 100.6 & 10.6 & -54.9 & 494.7 & 0.2 & 240 & 286.1 & 8.2 & 192.8 & 322.8 & 2.3 & 590 \\
\hline \multirow[t]{6}{*}{$\mathrm{TZ}$} & \multirow[t]{2}{*}{25} & 0 & 150 & 172.5 & 7.8 & -47.4 & 334.9 & 27.2 & 60 & 591.1 & 18.0 & 235.8 & 306.0 & 91.3 & 210 \\
\hline & & $\mathrm{T}$ & 375 & 172.5 & 7.8 & 100.6 & 401.5 & 37.6 & 240 & 591.1 & 18.0 & 88.8 & 309.2 & 415.1 & 615 \\
\hline & \multirow[t]{2}{*}{50} & 0 & 225 & 99.3 & 9.6 & -45.3 & 356.0 & 4.0 & 120 & 404.5 & 18.0 & 135.8 & 342.2 & 28.5 & 345 \\
\hline & & $\mathrm{T}$ & 375 & 99.3 & 9.6 & 71.4 & 388.3 & 5.0 & 240 & 404.5 & 18.0 & 69.5 & 346.4 & 210.6 & 615 \\
\hline & \multirow[t]{2}{*}{75} & 0 & 300 & 68.3 & 6.7 & -34.9 & 390.4 & 6.1 & 180 & 341.0 & 14.6 & 136.0 & 336.1 & 34.3 & 480 \\
\hline & & $\mathrm{T}$ & 375 & 68.3 & 6.7 & 17.6 & 411.5 & 7.5 & 240 & 341.0 & 14.6 & 101.5 & 341.6 & 123.3 & 615 \\
\hline \multirow[t]{6}{*}{ YC } & \multirow[t]{2}{*}{25} & 0 & 60 & 219.8 & 7.4 & -122.9 & 332.5 & 62.8 & 60 & 487.3 & 14.3 & 114.1 & 324.1 & 94.8 & 120 \\
\hline & & $\mathrm{T}$ & 300 & 219.8 & 7.4 & -89.8 & 447.2 & 155.0 & 240 & 487.3 & 14.3 & 110.1 & 327.1 & 275.8 & 540 \\
\hline & \multirow[t]{2}{*}{50} & 0 & 120 & 141.0 & 10.9 & -144.9 & 338.9 & 56.1 & 120 & 381.0 & 17.0 & 202.5 & 319.0 & -37.5 & 240 \\
\hline & & $\mathrm{T}$ & 300 & 141.0 & 10.9 & -38.7 & 397.8 & 71.0 & 240 & 381.0 & 17.0 & 172.5 & 318.0 & 113.5 & 540 \\
\hline & \multirow[t]{2}{*}{75} & 0 & 120 & 101.4 & 11.6 & -293.4 & 369.7 & 133.5 & 120 & 266.0 & 14.0 & 71.7 & 284.8 & 15.5 & 240 \\
\hline & & $\mathrm{T}$ & 300 & 101.4 & 11.6 & -244.5 & 428.2 & 206.1 & 240 & 266.0 & 14.0 & 66.3 & 316.2 & 109.5 & 540 \\
\hline
\end{tabular}

Note: $I$ : irrigation, $P$ : precipitation, $P_{i}$ : rainfall interception, $\Delta W$ : change of soil water storage, ET: actual evapotranspiration, $R$ : groundwater recharge.

The $R$ during the rotation period under optimal irrigation scheduling reduced with respect to reference irrigation scheduling. The reduction value was $77.0 \mathrm{~mm}, 202.6 \mathrm{~mm}$ and $210.9 \mathrm{~mm}$ in LC, TZ and YC, respectively. The reduction of $R$ was uneven during growing season and demonstrated different behaviors among the three sites. For the LC site, the reduction of $R$ only occurred during maize season at 25\% PEP (228.8 mm), as evident in Fig. 5a. The reduction of $R$ in TZ was significant during maize season at all PEPs (with an average value of $198.4 \mathrm{~mm}$ ), whereas the reduction was not evident during winter wheat season (Fig. 6). In contrast to LC and TZ sites, the reduction of $R$ in YC occurred throughout the double cropping seasons (Fig. 7). The average reduction of $R$ during winter wheat and summer maize season was 59.9 and $142 \mathrm{~mm}$, respectively. Furthermore, groundwater even contributed $37.5 \mathrm{~mm}$ to crop water consumption in summer maize season under optimal irrigation scheduling for the YC site at 50\% PEP.

It was expected that high evapotranspiration, low soil water storage change and low groundwater recharge usually occurred at the groundwater-affected area (YC site), which was somewhat different from the comparison results among the three sites in Table 7. This was due to that the water balance components were also affected by the soil hydraulic properties, crop varieties and root growth, and evaporative demand.

\section{Discussion}

\subsection{Impacts of precipitation, soil and water table depth on evapotranspiration}

The amount of precipitation and its seasonal distribution directly affected the variation of ET. During the growing period of winter wheat, precipitation could meet $37.9 \%, 30.1 \%$ and $42.2 \%$ of ET under optimal irrigation scheduling at the LC, TZ and YC site, respectively. The water deficit was so significant in the winter wheat season that precipitation had a positive effect on ET. For example, the precipitation contributed most (63.9\%) to ET at 25\% PEP for the YC site but least (15.8\%) at 75\% PEP for the TZ site. In contrast, precipitation during summer maize season was greater than crop water demand except in dry years. Although precipitation was a major source of ET, excessive rainfall would have negative effects on ET.
Water table depth also plays an important role in variations of ET, especially in shallow water table area. Soil moisture in the root zone could be recharged by capillary flux from shallow groundwater, which sped up the groundwater evaporation. The capillary rise even reached $46.2 \%$ of ET under optimal irrigation practice in the summer maize season at $50 \%$ PEP for the YC site. The ratio of seasonal groundwater evaporation to potential evapotranspiration could be described by an exponential function of water table depth at the YC site (Luo and Sophocleous, 2010). However, the contribution of groundwater to ET gradually reduced with decreasing water table depth (Cooper et al., 2006). This was evident at both the LC and $\mathrm{TZ}$ sites. Even though there was not enough precipitation at the critical growing stages, groundwater contributed little to ET (see Figs. 5 and 6).

The extinction water table depth of groundwater evaporation is approximately $4 \mathrm{~m}$ in the NCP, with slight differences among different irrigations, climates and vegetation (Lei et al., 1992; Luo and Sophocleous, 2010). Shah et al. (2007) indicated that the extinction depth varied significantly from $0.50 \mathrm{~m}$ to $8.20 \mathrm{~m}$ for 12 soil-land cover combinations. The approximately extinction depth of $4 \mathrm{~m}$ in the NCP was very close to that for the combination of the shallow rooted grass and loam soil $(3.7 \mathrm{~m})$ in Shah et al. (2007). If the thickness of unsaturated zone is out of this range, there is no direct evaporation from the groundwater table. Instead, unsaturated flow occurs and soil water storage in the root zone is crucial for ET.

The storage capacity is significantly affected by soil texture. Compared to coarse textured soil, medium and fine textured soil could retain more soil moisture for ET by root water uptake. For example, the contribution of soil water storage to ET at the LC site was found to be $12 \%$ larger than that at the TZ site during winter wheat season. This was due to that there was higher proportion of silt and clay contents in the soil layers of the LC site with respect to that of the $\mathrm{TZ}$ site.

\subsection{Impacts of precipitation, soil and water table depth on groundwater recharge}

The amount of groundwater recharge depended mostly on the local precipitation and irrigation. The more precipitation usually resulted in greater groundwater recharge in each representative 

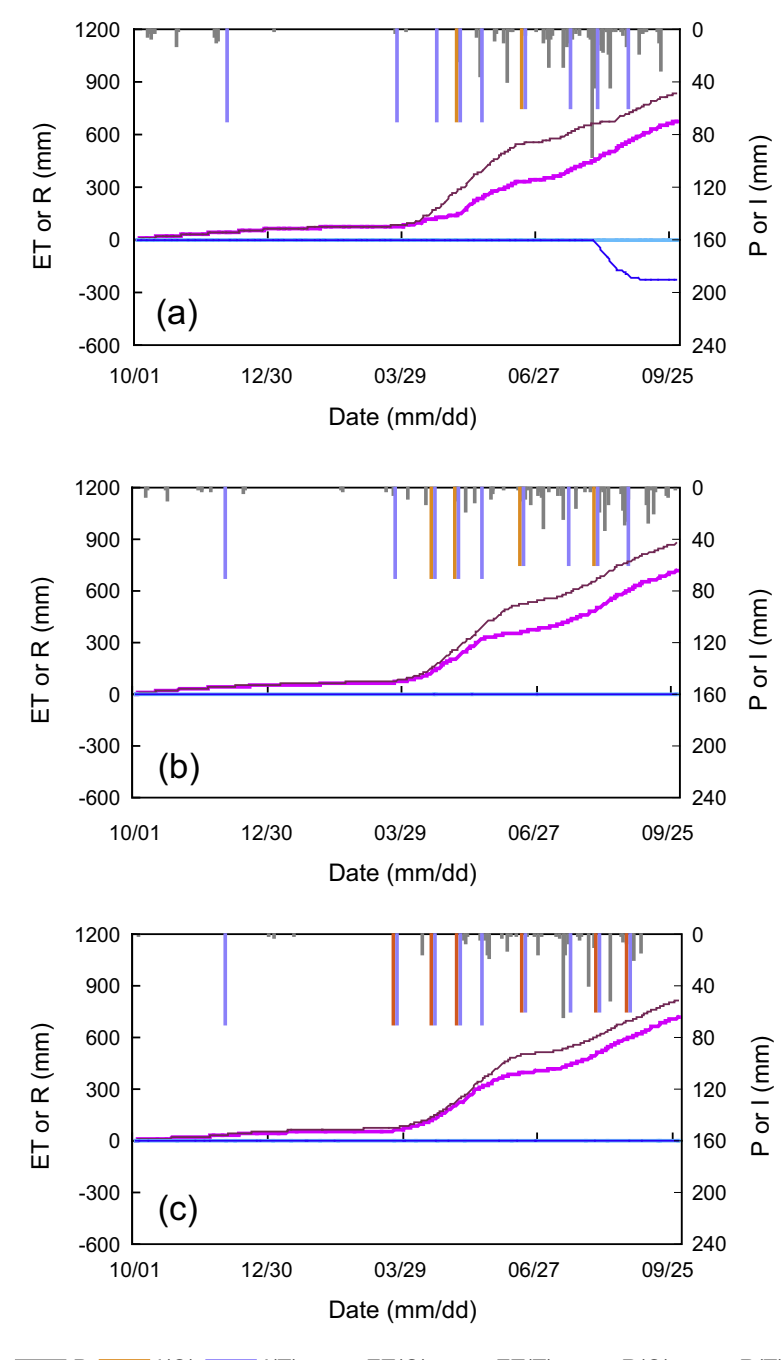

$P \mathrm{P}=\mathrm{I}(\mathrm{O}) \amalg \mathrm{I}(\mathrm{T}) \longrightarrow \mathrm{ET}(\mathrm{O}) \longrightarrow \mathrm{ET}(\mathrm{T}) \longrightarrow \mathrm{R}(\mathrm{O}) \longrightarrow \mathrm{R}(\mathrm{T})$

Fig. 5. Temporal variations of cumulative actual evapotranspiration (ET) and groundwater recharge $(R)$, daily precipitation $(P)$ and irrigation $(I)$ for the optimal and reference irrigation scheduling (abbreviated as (O) and (T)) at (a) 25\%, (b) 50\% and (c) 75\% precipitation exceedance probabilities (PEPs) at the LC site.

site. According to the reports of Kendy et al. (2004), the fraction of recharge accounting for precipitation plus irrigation increased with water input. Furthermore, the relationship between precipitation and groundwater recharge was also affected by the variation of water table depth, especially in shallow water table area. The YC site had deeper water table depth (varying between 2.6 and $3.7 \mathrm{~m}$ ) at 50\% PEP with respect to that at 75\% PEP (varying between 0.7 and $3.1 \mathrm{~m}$ ). Same irrigation amount was applied at the two years and precipitation in the normal year $(522.0 \mathrm{~mm})$ was more than that in the dry year $(367.4 \mathrm{~mm})$. However, the groundwater recharge under optimal irrigation scheduling at 50\% PEP $(18.6 \mathrm{~cm})$ was significantly less than that at $75 \%$ PEP $(149.0 \mathrm{~cm})$.

The water table depth and soil texture mainly influenced the time delays of groundwater recharge relative to the precipitation and irrigation events (Ma et al., 2010). The infiltrated water reached the water table very quickly in shallow water table area. The time-lag between the individual rainfall events and infiltration recharges was short at the YC site. As the water table depth increased, the delay of groundwater recharge relative to the rainfall and irrigation events was great at the LC and $\mathrm{TZ}$ sites. It was reported that the peak time-lags were about 18-35 days in the piedmont plain and 3-5 days in the central alluvial and lacustrine
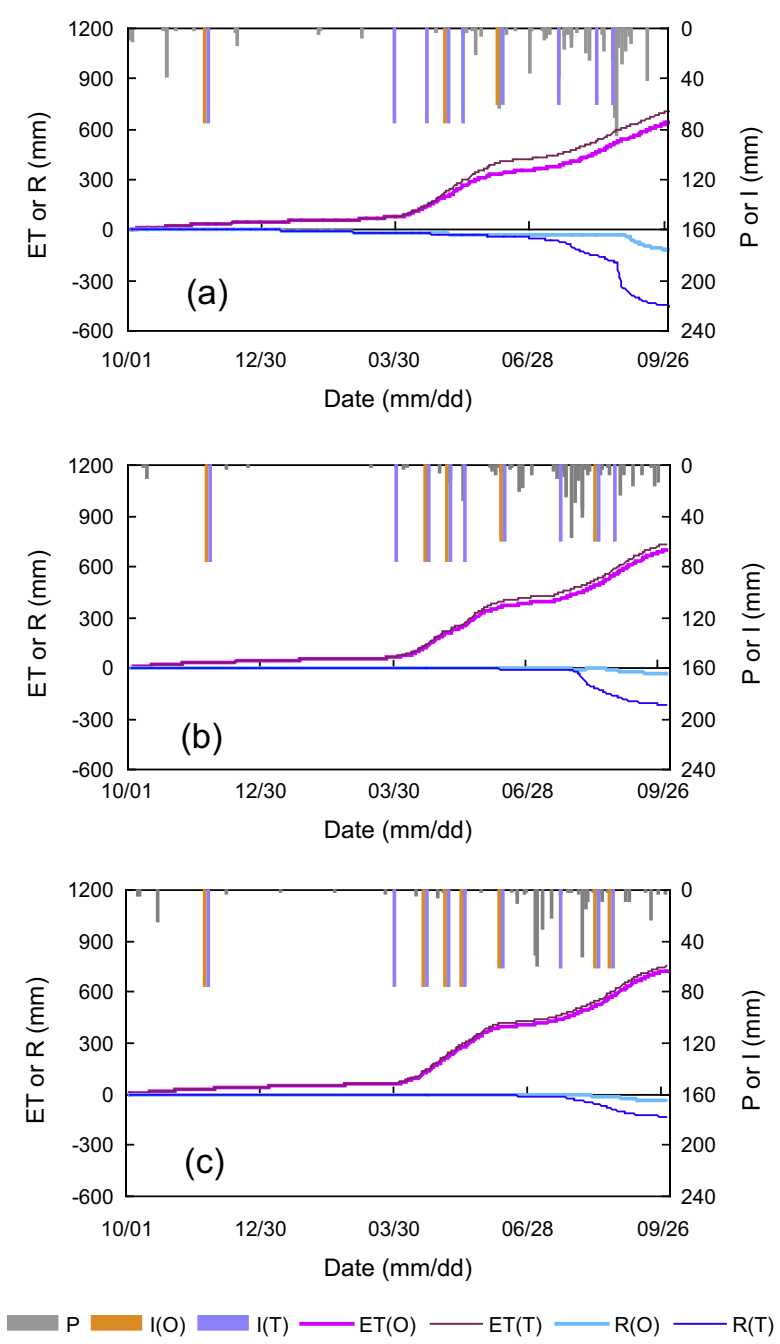

Fig. 6. Temporal variations of cumulative actual evapotranspiration (ET) and groundwater recharge $(R)$, daily precipitation $(P)$ and irrigation $(I)$ for the optimal and reference irrigation scheduling (abbreviated as (O) and (T)) at (a) 25\%, (b) $50 \%$ and (c) 75\% precipitation exceedance probabilities (PEPs) at the TZ site.

plains, but only 1 or 2 days in the coastal plain within the NCP (Lu et al., 2011).

In the deep water table area such as the $\mathrm{LC}$ and $\mathrm{TZ}$ sites, several separate rainfalls needed to be merged into one single infiltration process to produce groundwater recharge. At the TZ site, recharge generally followed by intensive or continuous rainfall events, and most of recharge occurred in summer maize season. However, little recharge was simulated at the LC site. This was due to that infiltrated water in the root zone with finer textured soils had much more residence time before evapotranspiration. Furthermore, the water table was too deep that the pathway for percolated water was noticeably tortuous.

\subsection{Implications for water resources management}

The water saving under optimal irrigation scheduling mainly occurred in winter wheat season from the results of this study. The irrigated area of winter wheat was about $1.2 \times 10^{6}$ ha in the NCP according to statistical database of Chinese economic and social development in 2006. Compared to traditional irrigation water use, the optimal irrigation scheduling for the LC, TZ and YC sites would reduce the irrigation amount of $2.2 \times 10^{9}, 2.7 \times 10^{9}$ and $1.3 \times 10^{9} \mathrm{~m}^{3}$ in the $\mathrm{NCP}$, respectively. All of the irrigation water savings exceeded the goal of $9.8 \times 10^{8} \mathrm{~m}^{3}$ for wheat in 

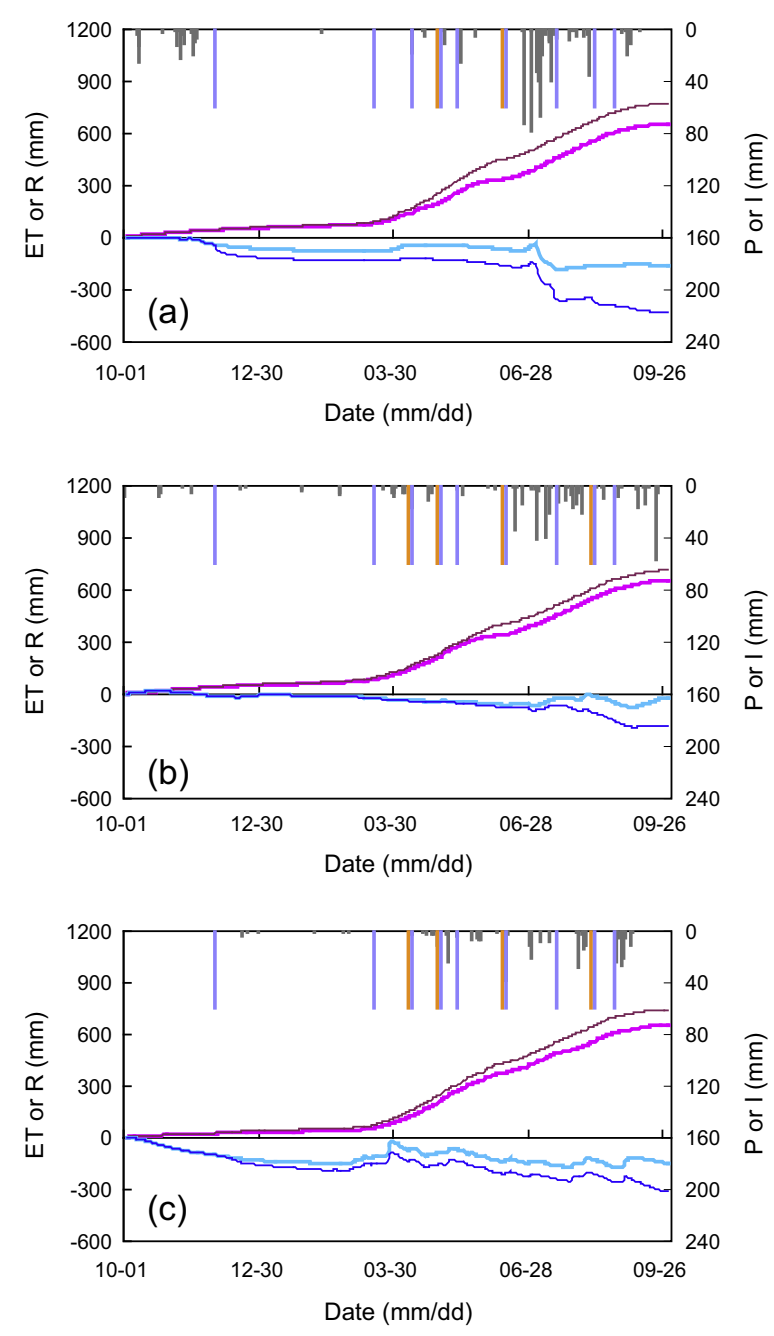

$\mathrm{P} \quad \mathrm{I}(\mathrm{O})-\mathrm{I}(\mathrm{T}) \longrightarrow \mathrm{ET}(\mathrm{O})-\mathrm{ET}(\mathrm{T}) \longleftarrow \mathrm{R}(\mathrm{O})-\mathrm{R}(\mathrm{T})$

Fig. 7. Temporal variations of cumulative actual evapotranspiration (ET) and groundwater recharge $(R)$, daily precipitation $(P)$ and irrigation $(I)$ for the optimal and reference irrigation scheduling (abbreviated as (O) and (T)) at (a) $25 \%$, (b) $50 \%$ and (c) 75\% precipitation exceedance probabilities (PEPs) at the YC site.

2010. In the NCP, about $82.5 \%$ of the irrigation water was from groundwater, and the average overexploitation of groundwater was about $2.4 \times 10^{9} \mathrm{~m}^{3} \mathrm{yr}^{-1}$ since 2000 (Zhang et al., 2012). The amount of exploited groundwater could be averagely reduced by $1.7 \times 10^{9} \mathrm{~m}^{3}$ with application of the optimal irrigation scheduling. This reduction reached about $70.1 \%$ of the overexploited amount, which could play an important role in protecting the limited groundwater resources in the NCP.

However, groundwater level still declined under the optimal irrigation scheduling due to the reduction of recharge. For example, assuming that the specific yield of the aquifer was 0.2 (Kendy et al., 2004) and all the irrigation came from groundwater, potential decline in water table under the optimal irrigation scheduling was about $1.30 \mathrm{~m} \mathrm{yr}^{-1}$ in LC. This result roughly matched the calculated groundwater level decline of about 1$1.5 \mathrm{~m} \mathrm{yr}^{-1}$ in LC by the other studies (Chen et al., 2010; Kendy et al., 2004; Zhang et al., 2003).

\subsection{Further scopes of this study}

The differences of optimal irrigation scheduling and groundwater recharge at three representative sites were thoroughly compared in this study. This is very important for the water resources sustainable use and food safety in the NCP. However, there were several issues still needing further studies. Firstly, the same PEP of $25 \%, 50 \%$ and $75 \%$ was selected for the double crops in this study. This choice had highest frequency in certain hydrological year. Moreover, it was commonly used in previous studies considering the availability of data. However, the winter wheat and summer maize in the double cropping system definitely had the interaction. This interaction of the PEP for the summer maize and winter wheat would affect the ET and R. To accurately evaluate the effect of the different combined PEP years on the water balance, the remaining scenarios of any two PEPs combination between winter wheat and summer maize should also be taken into account for further simulation.

Secondly, long-term simulations were needed to fully investigate the effects of variation in climate on irrigation scheduling and groundwater recharge as well as nutrient cycle (Qi et al., 2012). The simulation was conducted at three typical hydrological years in this study. Due to inter-annual climatic variability, the varied vegetation parameters would result in variation of the vegetation water-use. The vegetation dynamics affected by climate variability exerted significant controls on simulated annual groundwater recharge.

Thirdly, recent versions of the model SWAP with the Wofost model for crop growth (van Dam et al., 2008; Kroes and Supit, 2011) should be used in future studies. It can simulate the actual yield, and the water use efficiency can be obtained for optimizing the irrigation practices.

Finally, more sites in the NCP should be chosen for water balance and crop response coupling simulation to obtained a plain overview. Three representative sites in different geomorphologic zones of the NCP were selected in this study. To fully account for the spatial variability of climate, soil and groundwater conditions in the NCP, the irrigation scheduling and groundwater recharge simulations should be expanded to more sites if the data is available. This is very useful for water resources management on the regional scale.

\section{Conclusion}

In this study, the SWAP model was established at three distinct sites (LC, TZ and YC) in the NCP to evaluate the optimal irrigation scheduling and groundwater recharge for winter wheat-summer maize double cropping system. The effects of precipitation, soil texture and water table depth on evapotranspiration and groundwater recharge were explored. The following conclusions could be drawn from this study:

1. The optimal irrigation amount for the double cropping system was 130,260 and $390 \mathrm{~mm}$ in hydrological years of $25 \%, 50 \%$ and $75 \%$ PEPs at the LC site, 210,345 and $480 \mathrm{~mm}$ at the TZ site, and 120, 240 and $240 \mathrm{~mm}$ at the YC site, respectively. More irrigation amount and additional irrigation at the winter-dormancy stage of winter wheat was needed in $\mathrm{TZ}$ at each year. For summer maize, the optimal irrigation schedulings at the three sites were nearly same, except that no irrigation was needed at filling stage at $75 \%$ PEP in YC.

2. The optimal irrigation scheduling made the best of soil water storage and reduced the groundwater recharge from irrigation, which decreased the exploitation from groundwater reservoir for irrigation. With respect to the reference irrigation practice, the groundwater recharge under optimal irrigation scheduling reduced by $77.0 \mathrm{~mm}, 202.6 \mathrm{~mm}$ and $201.9 \mathrm{~mm}$ at the LC, TZ and YC sites, respectively. The groundwater recharge occurred throughout the double cropping seasons at the YC site, but it occurred only in summer maize season at the LC and TZ sites. 
3. The precipitation, soil texture and water table depth jointly affected the amount of groundwater recharge and time-lag between water input and groundwater recharge. Fine textured soil and deep water table in LC facilitated to make full use of precipitation and soil water storage. Intensive rainfall and coarser textured soils promoted groundwater recharge in $\mathrm{TZ}$ during summer maize season. Shallow water table in YC resulted in rapid groundwater recharge process and evident contribution of groundwater to crop evapotranspiration.

\section{Acknowledgements}

This research was partially supported by the National Natural Science Foundation of China (Grant No. 41101029), the Key Project for the Strategic Science Plan in IGSNRR, CAS (Grant No. 2012ZD003), Open Fund from State Key Laboratory of Soil and Sustainable Agriculture (Grant No. 0812201245). We thank Yin Shiyang for providing the water table data in TZ. We thank the anonymous reviewers for their constructive comments which improved the quality of this manuscript.

\section{References}

Cao, G.L., Zheng, C.M., Scanlon, B.R., Liu, J., Li, W.P., 2013. Use of flow modeling to assess sustainability of groundwater resources in the North China Plain. Water Resour. Res. 49, 1-17.

Chen, C., Wang, E.L., Yu, Q., 2010. Modelling the effects of climate variability and water management on crop water productivity and water balance in the North China Plain. Agr. Water Manage. 97, 1175-1184.

Chen, Z.Y., Nie, Z.L., Zhang, Z.J., Qi, J.X., Nan, Y.J., 2005. Isotopes and sustainability of ground water resources, North China Plain. Ground Water 43, 485-493.

Cooper, D.J., Sanderson, J.S., Stannard, D.I., Groeneveld, D.P., 2006. Effects of longterm water table drawdown on evapotranspiration and vegetation in an arid region phreatophyte community. J. Hydrol. 325, 21-34.

Doherty, J., 2002. PEST: model-independent parameter estimation. User Manual, fourth ed. Watermark Numerical Computing, Brisbane, QLD, Australia.

Doorenbos, J., Kassam, A. H., 1979. Yield response to water. FAO Irrigation and Drainage Paper 33, FAO, Rome, Italy.

Droogers, P., Torabi, M., Akbari, M., Pazira, E., 2001. Field-scale modeling to explore salinity problems in irrigated agriculture. Irrig. Drain. 50, 77-90.

Edmunds, W.M. (Ed.), 2001. Isotope based assessment of groundwater renewal in water scarce regions. IAEA TECDOC 1246. Int. Atomic Energy Agency, Vienna.

Fang, Q.X., Chen, Y.H., Yu, Q., Ouyang, Z., Li, Q.Q., Yu, S.Z., 2007. Much improved irrigation use efficiency in an intensive wheat-maize double cropping system in the North China Plain. J. Integr. Plant Biol. 49, 1517-1526.

Fereres, E., Soriano, M.A., 2007. Deficit irrigation for reducing agricultural water use. J. Exp. Bot. 58, 147-159.

Fu, G.B., Charles, S.P., Yu, J.J., Liu, C.M., 2009. Decadal climatic variability, trends, and future scenarios for the North China Plain. J. Climate 22, 2111-2123.

Huo, Z., Feng, S., Dai, X., Zheng, Y., Wang, Y., 2012. Simulation of hydrology following various volumes of irrigation to soil with different depths to the water table. Soil Use Manage. 28, 229-239.

Jan, C.D., Chen, T.H., Lo, W.C., 2007. Effect of rainfall intensity and distribution on groundwater level fluctuations. J. Hydrol. 332, 348-360.

Kang, S.Z., Zhang, L., Liang, Y.L., Hu, X.T., Cai, H.J., Gu, B.J., 2002. Effects of limited irrigation on yield and water use efficiency of winter wheat in the Loess Plateau of China. Agr. Water Manage. 55, 203-216.

Kendy, E., Gérard-Marchant, P., Walter, M.T., Zhang, Y.Q., Liu, C.M., Steenhuis, T.S. 2003. A soil-water-balance approach to quantify groundwater recharge from irrigated cropland in the North China Plain. Hydrol. Process. 17, 2011-2031.

Kendy, E., Zhang, Y.Q., Liu, C.M., Wang, J.X., Steenhuis, T., 2004. Groundwater recharge from irrigated cropland in the North China Plain: case study of Luancheng County, Hebei Province, 1949-2000. Hydrol. Process. 18, 22892302.

Kim, J.H., Jackson, R.B., 2012. A global analysis of groundwater recharge for vegetation, climate and soils. Vadose Zone J. 11. http://dx.doi.org/10.2136/ vzj2011.0021RA.

Kroes, J.G., Supit, I., 2011. Impact analysis of drought, water excess and salinity on grass production in The Netherlands using historical and future climate data. Agr. Ecosyst. Environ. 144, 370-381.
Lei, Z.D., Yang, S.X., Ni, G.H., Xue, Y.Z., 1992. Water continuum feature in response to the type of groundwater level. J. Hydraul. Eng. 21, 1-6 (in Chinese).

Li, J.M., Inanaga, S.B., Li, Z.H., Eneji, A.E., 2005. Optimizing irrigation scheduling for winter wheat in the North China Plain. Agr. Water Manage. 76, 8-23.

Liu, C.M., Zhang, X.Y., Zhang, Y.Q., 2002. Determination of daily evaporation and evapotranspiration of winter wheat and maize by large-scale weighting lysimeter and micro-lysimeter. Agr. For. Meteorol. 111, 109-120.

Liu, Y., Pereira, L.S., Fernando, R.M., 2006. Fluxes through the bottom boundary of the root zone in silty soils: parametric approaches to estimate groundwater contribution and percolation. Agr. Water Manage. 84, 27-40.

Lu, X.H., Jin, M.G., van Genuchten, M.Th., Wang, B.G., 2011. Groundwater recharge at five representative sites in the Hebei Plain, China. Ground Water 49, 286-294.

Luo, Y., Sophocleous, M., 2010. Seasonal groundwater contribution to crop-water use assessed with lysimeter observations and model simulations. J. Hydrol. 389, 325-335.

Ma, Y., Feng, S.Y., Huo, Z.L., Song, X.F., 2011. Application of the SWAP model to simulate the field water cycle under deficit irrigation in Beijing, China. Math. Comput. Model. 54, 1044-1052.

Ma, Y., Feng, S.Y., Su, D.Y., Gao, G.Y., Huo, Z.L., 2010. Modeling water infiltration in a large soil column with a modified Green-Ampt model and HYDRUS-1D. Comput. Electron. Agric. 71S, S40-S47.

Mo, X.G., Liu, S.X., Lin, Z.H., Guo, R.P., 2009. Regional crop yield, water consumption and water use efficiency and their responses to climate change in the North China Plain. Agr. Water Manage. 134, 67-78.

Qi, Z.M., Bartling P.N.S, Ahuja, L.R, Derner, J.D., Dunn, G.H. Ma, LW. 2012. Development and evaluation of the carbon-nitrogen cycle module for the GPFARM-Range model. Comput. Electron. Agric. 83, 1-10.

Roman, R., Caballero, R., Bustos, A., 1999. Field water drainage under traditional and improved irrigation schedules for corn in central Spain. Soil Sci. Soc. Am. J. 63, 1811-1917.

Sarwar, A., Bastiaanssen, W.G.M., Boers, Th.M., Van Dam, J.C., 2000. Evaluating drainage design parameters for the fourth drainage project, Pakistan by using SWAP model: Part I-calibration. Irrig. Drain. Syst. 14, 257-280.

Schaap, M.G., Leij, F.J., van Genuchten, M.Th., 1998. Neural network analysis for hierarchical prediction of soil hydraulic properties. Soil Sci. Soc. Am. J. 62, $847-$ 855.

Shang, S.H., Mao, X.M., Lei, Z.D., Yang, S.X., 2009. Soil Moisture Dynamic Simulation Modeling and Its Application, first ed. Science Press, Beijing (in Chinese).

Shah, N., Nachabe, M., Ross, M., 2007. Extinction depth and evapotranspiration from ground water under selected land covers. Ground Water 45, 329-338.

Stonestrom, D.A., Constantz, J., Ferré, T.P.A., Leake, S.A. (Eds.), 2007. Ground-Water Recharge in the Arid and Semiarid Southwestern United States. Prof. Pap. 1703. USGS, Denver CO.

Sun, H.Y., Shen, Y.J., Yu, Q., Flerchinger, G.N., Zhang, Y.Q., Liu, C.M., Zhang, X.Y., 2010 Effect of precipitation change on water balance and WUE of the winter wheatsummer maize rotation in the North China Plain. Agr. Water Manage. 97, 11391145.

van Dam, J.C., Huygen, J., Wesseling, J.G., Feddes, R.A., Kabat, P., van Walsum, P.E.V., Groenendijk, P., van Diepen, C.A., 1997. Theory of SWAP version 2.0. Simulation of water flow, solute transport and plant growth in the Soil-Water-Air-Plant environment. Report 71, Department of Water Resources, Wageningen Agricultural University, Tech. Docu. 45, DLO Winand Staring Centre, Wageningen, the Netherlands.

van Dam, J.C., Groenendijk, P., Hendriks, R.F.A., Kroes, J.G., 2008. Advances of modeling water flow in variably saturated soils with SWAP. Vadose Zone J. 7 640-653.

van Genuchten, M.Th., Leij, F.J., Yates, S.R., 1991. The RETC Code for Quantifying the Hydraulic Functions of Unsaturated Soils. Salinity Laboratory, U.S Department of Agriculture, Agricultural Research Service, Riverside, California, USA.

Wang, B.G., Jin, M.G., Nimmo, J.R., Yang, L., Wang, W.F., 2008. Estimating groundwater recharge in Hebei Plain, China under varying land use practices using tritium and bromide tracers. J. Hydrol. 356, 209-222.

Wang, X.P., Huang, G.H., 2008. Evaluation on the irrigation and fertilization management practices under the application of treated sewage water in Beijing, China. Agr. Water Manage. 95, 1011-1027.

Zhang, G.H., Fei, Y.H., Wang, J.Z., Yan, M.J., 2012. Study on Adaptability of Irrigated Agriculture and Groundwater in North China, first ed. Science Press, Beijing (in Chinese).

Zhang, X.Y., Pei, D., Chen, S.Y., Sun, H.Y., Yang, Y.H., 2006. Performance of doublecropped winter wheat-summer maize under minimum irrigation in the North China Plain. Agron. J. 98, 1620-1626.

Zhang, X.Y., Pei, D., Hu, C.S., 2003. Conserving groundwater for irrigation in the North China Plain. Irrig. Sci. 21, 159-166.

Zhang, Y.Q., Kendy, E., Yu, Q., Liu, C.M., Shen, Y.J., Sun, H.Y., 2004. Effect of soil water deficit on evapotranspiration, crop yield, and water use efficiency in the North China Plain. Agr. Water Manage. 64, 107-122. 